\title{
Commentary: Acute kidney injury: The one-million-pieces puzzle
}

Lorenzo Di Bacco, MD, ${ }^{a}$ Andrea Montisci, MD, ${ }^{\mathrm{b}}$ and Antonio Miceli, $\mathrm{MD}, \mathrm{PhD}^{\mathrm{a}}$

\author{
From the Departments of ${ }^{a}$ Minimally Invasive Cardiac Surgery and ${ }^{\mathrm{b}}$ Anesthesia and Intensive Care, Cardiotho- \\ racic Center, Istituto Clinico Sant'Ambrogio, Milan, Italy. \\ Disclosures: Authors have nothing to disclose with regard to commercial support. \\ Received for publication Nov 30, 2018; accepted for publication Nov 30, 2018; available ahead of print Jan 23 , \\ 2019. \\ Address for reprints: Antonio Miceli, MD, PhD, Department of Minimally Invasive Cardiac Surgery, Istituto Clin- \\ ico Sant'Ambrogio, Via Luigi Giuseppe Faravelli 16, Milan, Italy (E-mail: antoniomiceli79@alice.it). \\ J Thorac Cardiovasc Surg 2019;157:2367-8 \\ $0022-5223 / \$ 36.00$ \\ Copyright (c) 2018 by The American Association for Thoracic Surgery \\ https://doi.org/10.1016/j.jtcvs.2018.11.122
}

The prevention and treatment of postoperative acute kidney injury after cardiac surgery (CS-AKI) still remains an open issue in cardiac surgery, given its strong impact on patients' mortality and significant risk progression to chronic kidney disease. ${ }^{1,2}$ Despite several studies proposing pharmacologic and nonpharmacologic strategies to prevent and reduce the rate of postoperative AKI, $30 \%$ of patients undergoing cardiac surgery still experience CS-AKI and $8 \%$ require continuous renal-replacement therapy. ${ }^{2,3}$

In the current study, $\mathrm{Pu}$ and colleagues ${ }^{4}$ designed a randomized controlled study aiming to demonstrate whether amino acid infusion from the induction of anesthesia to discharge from the intensive care unit might improve postoperative renal function versus standard therapy in patients with reduced renal function. Although amino acid infusion did not show either a significant reduction in AKI rate or duration of renal dysfunction, a benefit was observed in reducing the duration of CS-AKI as well as greater estimated glomerular filtration rate and urine output.

This strategy, as shown in a previous study on intensive care unit patients, seems to mitigate the negative effects of cardiopulmonary bypass on kidney function., ${ }^{4,5}$ Interestingly, the increment of nitrogenous balance derived from amino acid infusion did not result in an incremented need of continuous renal-replacement therapy, as reported by other experiences. ${ }^{6}$ The possible efficacy of amino acids in preventing the progression of AKI is not a new finding, as the concept of renal arteriolar vasodilation, induced by amino acid infusion, was proposed 2 decades ago as a possible mechanism to improve renal perfusion.,

Some potentially confounding factors could be identified in this study. The lack of data regarding preoperative hemoglobin and hematocrit level during cardiopulmonary bypass could have overlooked the link between perioperative anemia and renal dysfunction. Furthermore, it would have been of interest to know the threshold for packed red blood cells transfusion to ensure an adequate oxygen delivery, a wellknown key factor to prevent postoperative AKI.,8

\section{References}

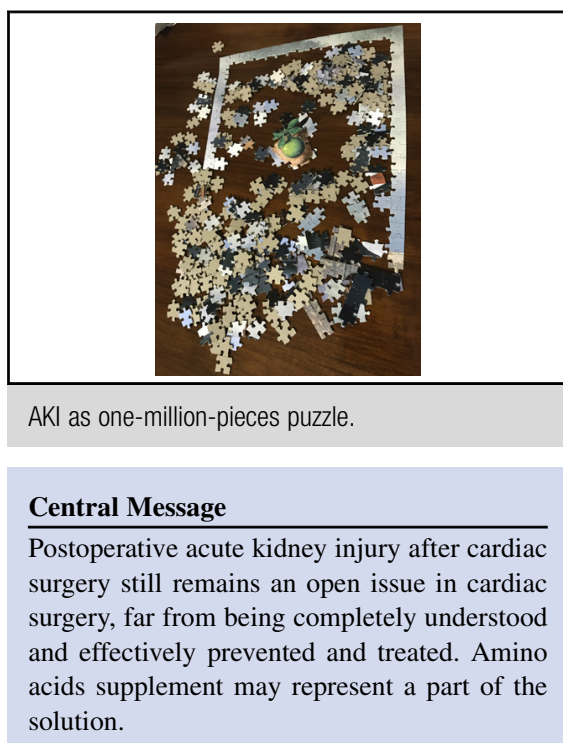

See Article page 2356.

To date, we have many reliable tools to predict the risk of AKI through the combination of clinical parameters and biological markers but not powerful strategies to prevent it. Techniques aimed at maximizing renal perfusion are promising, even if there is no evidence that they prevent all AKI stages. ${ }^{9,10}$ The unresolved issue of how to prevent AKI lies in wait, as not all of the renal noxae are effectively under the clinician's control. This study foresees an easily implementable tool into the clinical practice, but AKI remains a one-million-pieces puzzle.

1. Alshaikh HN, Katz NM, Gani F, Nagarajan N, Canner JK, Kacker S, et al. Financial impact of acute kidney injury after cardiac operations in the United States. Ann Thorac Surg. 2018;105:469-75.

2. Thiele RH, Isbell JM, Rosner MH. AKI associated with cardiac surgery. Clin J Am Soc Nephrol. 2015;10:500-14.

3. Hobson CE, Yavas S, Segal MS, Schold JD, Tribble CG, Layon AJ, et al. Acute kidney injury is associated with increased long-term mortality after cardiothoracic surgery. Circulation. 2009;119:2444-53.

4. Pu H, Doig GS, Heighes PT, Allingstrup MJ, Wang A, Brereton J, et al. Intravenous amino acid therapy for kidney protection in cardiac surgery patients: a pilo randomized controlled trial. J Thorac Cardiovasc Surg. 2019;157:2356-66.

5. Doig GS, Simpson F, Bellomo R, Heighes PT, Sweetman EA, Chesher D, et al. Intravenous amino acid therapy for kidney function in critically ill patients: a randomized controlled trial. Intensive Care Med. 2015;41:1197-208.

6. Sundström Rehal M, Liebau F, Tjäder I, Norberg A, Rooyackers O, Wernerman J A supplemental intravenous amino acid infusion sustains a positive protein balance for 24 hours in critically ill patients. Crit Care. 2017;21:298. 
7. Woods LL. Mechanisms of renal hemodynamic regulation in response to protein feeding. Kidney Int. 1993;44:659-75.

8. Ranucci M, Aloisio T, Carboni G, Ballotta A, Pistuddi V, Menicanti L, et al. Acute kidney injury and hemodilution during cardiopulmonary bypass: a changing scenario. Ann Thorac Surg. 2015;100:95-100.
9. Ranucci M, Johnson I, Willcox T, Baker RA, Boer C, Baumann A, et al. Goaldirected perfusion to reduce acute kidney injury: a randomized trial. J Thorac Cardiovasc Surg. 2018;156:1918-27.

10. Wang Y, Bellomo R. Cardiac surgery-associated acute kidney injury: risk factors, pathophysiology and treatment. Nat Rev Nephrol. 2017;13:697-711. 